\title{
Structure and Absolute Stereochemistry of Syphonoside, A Unique Macrocyclic Glycoterpenoid from Marine Organisms
}

\author{
Margherita Gavagnin, $*^{\dagger}$ Marianna Carbone, ${ }^{\dagger}$ Pietro Amodeo, ${ }^{\dagger}$ Ernesto Mollo, ${ }^{\dagger}$ \\ Rosa Maria Vitale, ${ }^{\ddagger}$ Vassilios Roussis, ${ }^{\S}$ and Guido Cimino $^{\dagger}$ \\ ${ }^{\dagger}$ Istituto di Chimica Biomolecolare, CNR, Via Campi Flegrei 34, 80078 Pozzuoli (Naples), Italy, ${ }^{\dagger}$ Istituto di \\ Biostrutture e Bioimmagini, CNR, Via Mezzocannone 16, 80134 Naples, Italy, and ${ }^{\S}$ Department of Pharmacognosy and \\ Chemistry of Natural Products, School of Pharmacy, University of Athens, Panepistimiopolis Zografou,15771 Athens, \\ Greece
}

\section{SUPPORTING INFORMATION}

\section{- ADDITONAL EXPERIMENTAL PROCEDURES}

Absolute stereochemistry determination of glucose at C-18 of compound $\mathbf{1}$. $\mathrm{S} 2$ Spectral data of $\alpha$ - and $\beta$-methyl-glucopyranose.

- $\quad$ SPECTRA OF COMPOUNDS 1-3

HR-ESIMS spectrum of 1

${ }^{13} \mathrm{C}-\mathrm{NMR}$ spectrum of $\mathbf{1} \quad$ S6

${ }^{1} \mathrm{H}-\mathrm{NMR}$ spectrum of $\mathbf{1} \quad$ S7

${ }^{1} \mathrm{H}-{ }^{1} \mathrm{H}$ COSY spectrum of $\mathbf{1} \quad$ S8

${ }^{1} \mathrm{H}-{ }^{1} \mathrm{H}$ COSY spectrum (glucose proton region) of $\mathbf{1}$

2D-TOCSY spectrum of $1 \quad$ S10

2D-TOCSY spectrum (glucose proton region) of $\mathbf{1}$ S11

$\begin{array}{ll}\text { HSQC spectrum of } \mathbf{1} & \text { S12 }\end{array}$

HMBC spectrum of $1 \quad$ S13

HMBC spectrum (key correlation region) of 12 S14

$\begin{array}{ll}{ }^{1} \mathrm{H}-\mathrm{NMR} \text { spectrum of } \mathbf{2} & \mathrm{S} 15\end{array}$

$\begin{array}{ll}{ }^{1} \mathrm{H}-\mathrm{NMR} \text { spectrum of } \mathbf{3} & \mathrm{S} 16\end{array}$

${ }^{1} \mathrm{H}-\mathrm{NMR}$ spectrum of $\alpha$-penta-benzoyl derivative of glucose from $\mathbf{1}$

${ }^{1} \mathrm{H}-\mathrm{NMR}$ spectrum of $\beta$-penta-benzoyl derivative of glucose from $1 \quad$ S18

${ }^{1} \mathrm{H}$-NMR spectrum $\alpha$-methyl-tetra-benzoyl derivative

$\begin{array}{ll}\text { of } \alpha \text {-methyl-glucopyranose from } 2 & \text { S19 }\end{array}$

$\begin{array}{ll}{ }^{1} \mathrm{H} \text {-NMR spectrum } \beta \text {-methyl-tetra-benzoyl derivative } & \mathrm{S} 20 \\ \text { of } \beta \text {-methyl-glucopyranose from } 2\end{array}$

CD profiles of $\beta$-penta-benzoyl derivatives of both commercial D-glucose
and the sample obtained from 1

CD profiles of $\beta$-methyl-tetra-benzoyl derivatives of both commercial

$\begin{array}{ll}\beta \text {-methyl-glucopyranose and the sample obtained from } 2 & \text { S22 }\end{array}$ 
Absolute stereochemistry determination of glucose at C-18 of compound 1. Benzoyl chloride

$(0.5 \mathrm{~mL})$ was added to a solution in dry pyridine $(1 \mathrm{~mL})$ of glucose $(3.0 \mathrm{mg})$ obtained after alkaline methanolysis of $\mathbf{1}$. The reaction mixture was stirred for $12 \mathrm{~h}$ at room temperature. After removal of the solvent under reduced pressure, the usual workup gave a mixture of $\alpha$ - and $\beta$-glucose pentabenzoates (1:1 ratio, as deduced by ${ }^{1} \mathrm{H}$ NMR). The obtained mixture was further purified on a Pasteur pipette silica gel column (light petroleum ether/diethyl ether gradient) to afford $0.8 \mathrm{mg}$ and $2.0 \mathrm{mg}$ of $\alpha$ - and $\beta$ - penta-benzoate derivatives, respectively. ${ }^{1} \mathrm{H}$ NMR values for $\alpha-$ derivative (300 MHz, $\left.\mathrm{CDCl}_{3}\right): \delta 8.16(\mathrm{~d}, J=7.4 \mathrm{~Hz}, 2 \mathrm{H}$, benzoyl ortho protons), $8.02(\mathrm{~d}, J=7.4 \mathrm{~Hz}, 2 \mathrm{H}$, benzoyl ortho protons), 7.94 (d, $J=7.4 \mathrm{~Hz}, 2 \mathrm{H}$, benzoyl ortho protons), 7.88 (d, $J=7.5 \mathrm{~Hz}, 4 \mathrm{H}$, benzoyl ortho protons), 7.69-7.26 (overlapping signals, 15H, benzoyl protons), 6.85 (d, $J=3.5 \mathrm{~Hz}$, $1 \mathrm{H}), 6.32(\mathrm{t}, J=9.9 \mathrm{~Hz}, 1 \mathrm{H}), 5.85(\mathrm{t}, J=10.7 \mathrm{~Hz}, 1 \mathrm{H}), 5.68(\mathrm{dd}, J=3.7$ and $10.1 \mathrm{~Hz}, 1 \mathrm{H}), 4.62(\mathrm{~m}$, 2H), $4.48(\mathrm{dd}, J=5.2$ and $13.1 \mathrm{~Hz}, 1 \mathrm{H}) .{ }^{1} \mathrm{H}$ NMR values for $\beta$ - derivative $\left(300 \mathrm{MHz}, \mathrm{CDCl}_{3}\right)$ : $\delta 8.03$ (bd, $J=7.9 \mathrm{~Hz}, 4 \mathrm{H}$, benzoyl ortho protons), 7.92 (d, $J=7.4 \mathrm{~Hz}, 4 \mathrm{H}$, benzoyl ortho protons), $7.86(\mathrm{~d}, J=7.4 \mathrm{~Hz}, 2 \mathrm{H}$, benzoyl ortho protons), 7.60-7.26 (overlapping signals, 15H, benzoyl protons), $6.29(\mathrm{~d}, J=7.9 \mathrm{~Hz}, 1 \mathrm{H}), 6.03(\mathrm{t}, J=9.4 \mathrm{~Hz}, 1 \mathrm{H}), 5.84(\mathrm{~m}, 2 \mathrm{H}), 4.66(\mathrm{dd}, J=2.7$ and 12.3 $\mathrm{Hz}, 1 \mathrm{H}), 4.51(\mathrm{dd}, J=4.7$ and $12.4 \mathrm{~Hz}, 1 \mathrm{H}), 4.41(\mathrm{~m}, 1 \mathrm{H}) . \mathrm{CD}$ ( $n$-hexane) $[\theta]_{248} 1194$ for the $\alpha$ derivative and $[\theta]_{219} 5878,[\theta]_{240}-3835$ for the $\beta$ derivative. ${ }^{1} \mathrm{H}$ NMR and CD spectra were identical with those of authentic samples prepared from D-glucose.

\section{Absolute stereochemistry determination of glucose at C-11 of compound 1. Benzoyl chloride}

$(0.5 \mathrm{~mL})$ was added to a dry pyridine solution $(1 \mathrm{~mL})$ of $\alpha$ - and $\beta$ - methyl-glucopyranoside mixture recovered from acid methanolysis of $\mathbf{2}$. The reaction was stirred for $12 \mathrm{~h}$ at room temperature. After removal of the solvent under reduced pressure, the usual workup afforded $\alpha-$ and $\beta$ - methyl-tetra-benzoyl-glucopyranoses in ratio of 2:1. The mixture was purified on a Pasteur pipette silica gel column (light petroleum ether/diethyl ether gradient) to afford $2.0 \mathrm{mg}$ and $0.9 \mathrm{mg}$ 
of pure $\alpha$ - and $\beta$-tetra-benzoate which were identified by comparison with authentic samples prepared from commercial $\alpha$-and $\beta$-methyl-glucopyranose, respectively. ${ }^{1} \mathrm{H}$ NMR values for $\alpha-$ derivative (600 MHz, $\left.\mathrm{CDCl}_{3}\right): \delta 8.06(\mathrm{~d}, J=7.4 \mathrm{~Hz}, 2 \mathrm{H}$, benzoyl ortho protons), 8.00 (d, $J=7.4$ $\mathrm{Hz}, 2 \mathrm{H}$, benzoyl ortho protons), 7.95 (d, $J=7.5 \mathrm{~Hz}, 2 \mathrm{H}$, benzoyl ortho protons), 7.89 (d, $J=7.6$ $\mathrm{Hz}, 2 \mathrm{H}$, benzoyl ortho protons), 7.64-7.26 (overlapping signals, $12 \mathrm{H}$, benzoyl protons), 6.21 (t, $J=$ $9.9 \mathrm{~Hz}, 1 \mathrm{H}), 5.70(\mathrm{t}, J=9.9 \mathrm{~Hz}, 1 \mathrm{H}), 5.32(\mathrm{dd}, J=3.6$ and $10.2 \mathrm{~Hz}, 1 \mathrm{H}), 5.27(\mathrm{~d}, J=3.6 \mathrm{~Hz}, 1 \mathrm{H})$, $4.63(\mathrm{dd},, J=2.8$ and $12.1 \mathrm{~Hz}, 1 \mathrm{H}), 4.51(\mathrm{dd}, J=5.3$ and $12.1 \mathrm{~Hz}, 1 \mathrm{H}), 4.44(\mathrm{~m}, 1 \mathrm{H}) .{ }^{1} \mathrm{H}$ NMR values for $\beta$-derivative (600 MHz, $\mathrm{CDCl}_{3}$ ): $\delta 8.03(\mathrm{~d}, J=7.3 \mathrm{~Hz}, 2 \mathrm{H}$, benzoyl ortho protons), 7.97 (d, $J=7.3 \mathrm{~Hz}, 2 \mathrm{H}$, benzoyl ortho protons), 7.90 (d, $J=7.4 \mathrm{~Hz}, 2 \mathrm{H}$, benzoyl ortho protons), 7.82 (d, $J=7.4 \mathrm{~Hz}, 2 \mathrm{H}$, benzoyl ortho protons), 7.62-7.26 (overlapping signals, $12 \mathrm{H}$, benzoyl protons), 5.92 $(\mathrm{t}, J=9.6 \mathrm{~Hz}, 1 \mathrm{H}), 5.69(\mathrm{t}, J=9.7 \mathrm{~Hz}, 1 \mathrm{H}), 5.53(\mathrm{~m}, 1 \mathrm{H}), 4.77(\mathrm{~d}, J=7.8 \mathrm{~Hz}, 1 \mathrm{H}), 4.65(\mathrm{dd}, J=$ 3.2 and $12.1 \mathrm{~Hz}, 1 \mathrm{H}), 4.52(\mathrm{dd}, J=5.2$ and $12.1 \mathrm{~Hz}, 1 \mathrm{H}), 4.17(\mathrm{~m}, 1 \mathrm{H}) . \mathrm{CD}$ (n-hexane) $[\theta]_{248} 1640$ for the $\alpha$ derivative and $[\theta]_{235} 613$ for the $\beta$ derivative.

Determination of cytotoxicity of compound 1. Cells were seeded into 96 -well plates $(100 \mu \mathrm{l} /$ well at a density of $1 \times 10^{5}$ cells $/ \mathrm{ml}$ ) and exposed to various concentrations of the compounds for 72 hours. The cytotoxicity was determined with the MTT [3-(4,5-dimethylthiazol-2-yl)-2,5diphenyltetrazolium bromide] dye reduction assay (ref. 24 of manuscript) as previously modified (ref. 25 of manuscript). Briefly, after incubation with the test compounds, MTT solution $(5 \mathrm{mg} / \mathrm{ml}$ in PBS) was added (20 $\mu \mathrm{l} /$ well). Plates were further incubated for 4 hours at $37^{\circ} \mathrm{C}$ and the formazan crystals formed were dissolved by adding $100 \mu \mathrm{l}$ /well of $0.1 \mathrm{~N} \mathrm{HCl}$ in 2-propanol. Absorption was measured by an enzyme-linked immunosorbant assay (ELISA) reader at $545 \mathrm{~nm}$, with reference filter at $690 \mathrm{~nm}$. For each concentration at least 9 wells were used from three separate experiments. One hundred microlitres of RPMI 1640 supplemented with the same amount of MTT solution and solvent was used as blank solution. Data obtained were presented as $\mathrm{IC}_{50}(\mu \mathrm{M})$, which is the 
concentration of the compound where $100 \times\left(\mathrm{A}_{0}-\mathrm{A}\right) / \mathrm{A}_{0}=50$. In this formula, $\mathrm{A}$ is the optical density of the wells after 72 hours of exposure to test compound and $A_{0}$ is the optical density of the control wells. 


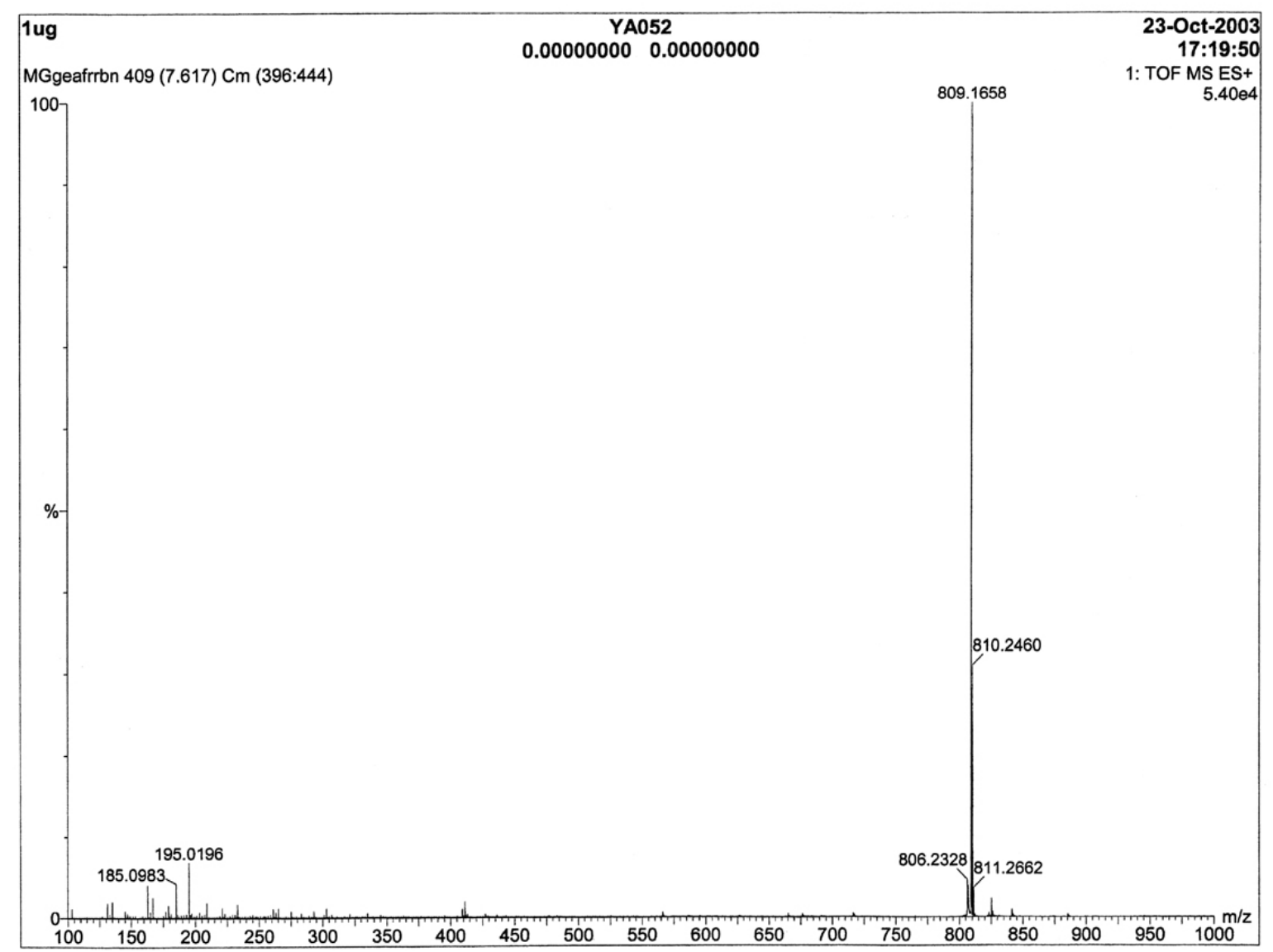

\section{Elemental Composition Report}

\section{Single Mass Analysis}

Tolerance $=20.0$ PPM / DBE: $\min =-1.5, \max =50.0$

Isotope cluster parameters: Separation $=1.0$ Abundance $=1.0 \%$

Monoisotopic Mass, Odd and Even Electron Ions

58 formula(e) evaluated with 4 results within limits (up to 50 closest results for each mass)

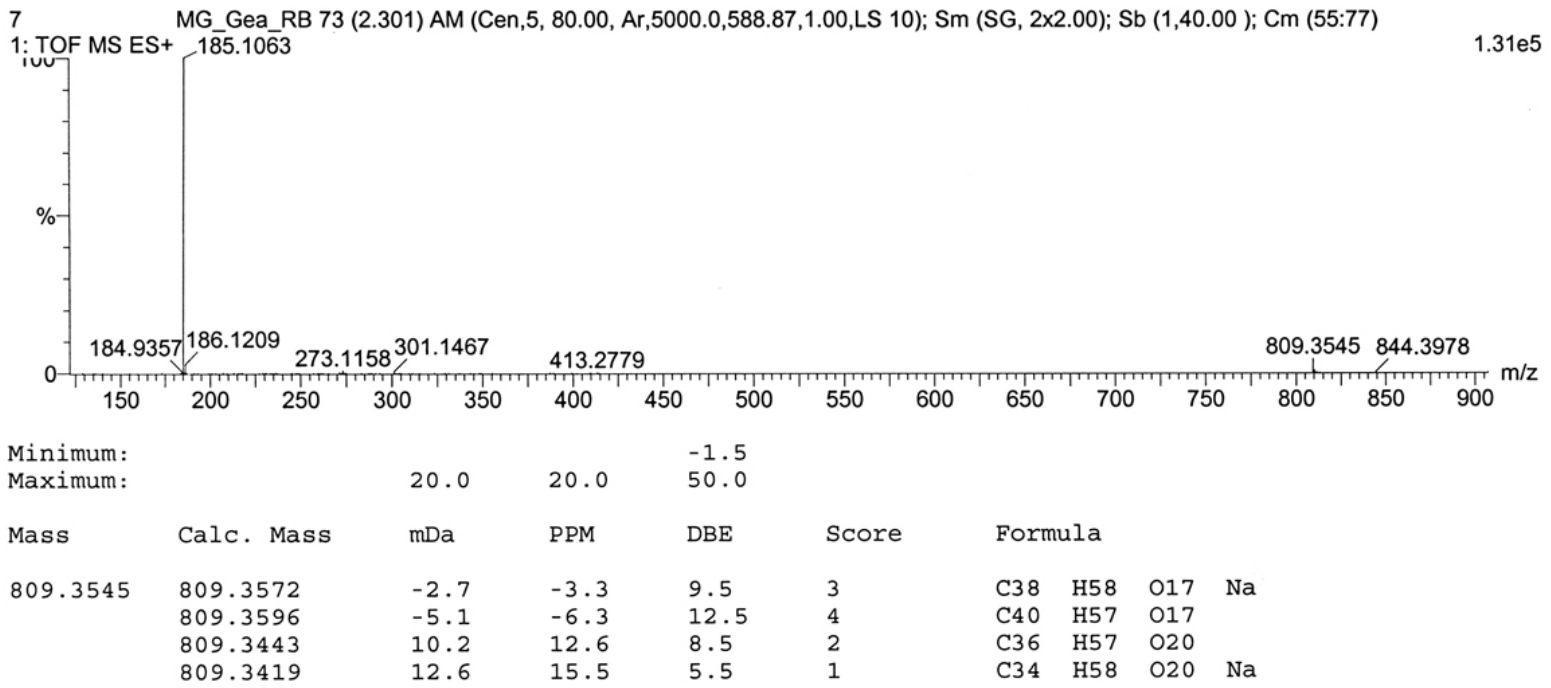

HR-ESIMS spectrum of 1 (Micromass Q-TOF Micro coupled with HPLC Waters Alliance 2695). 


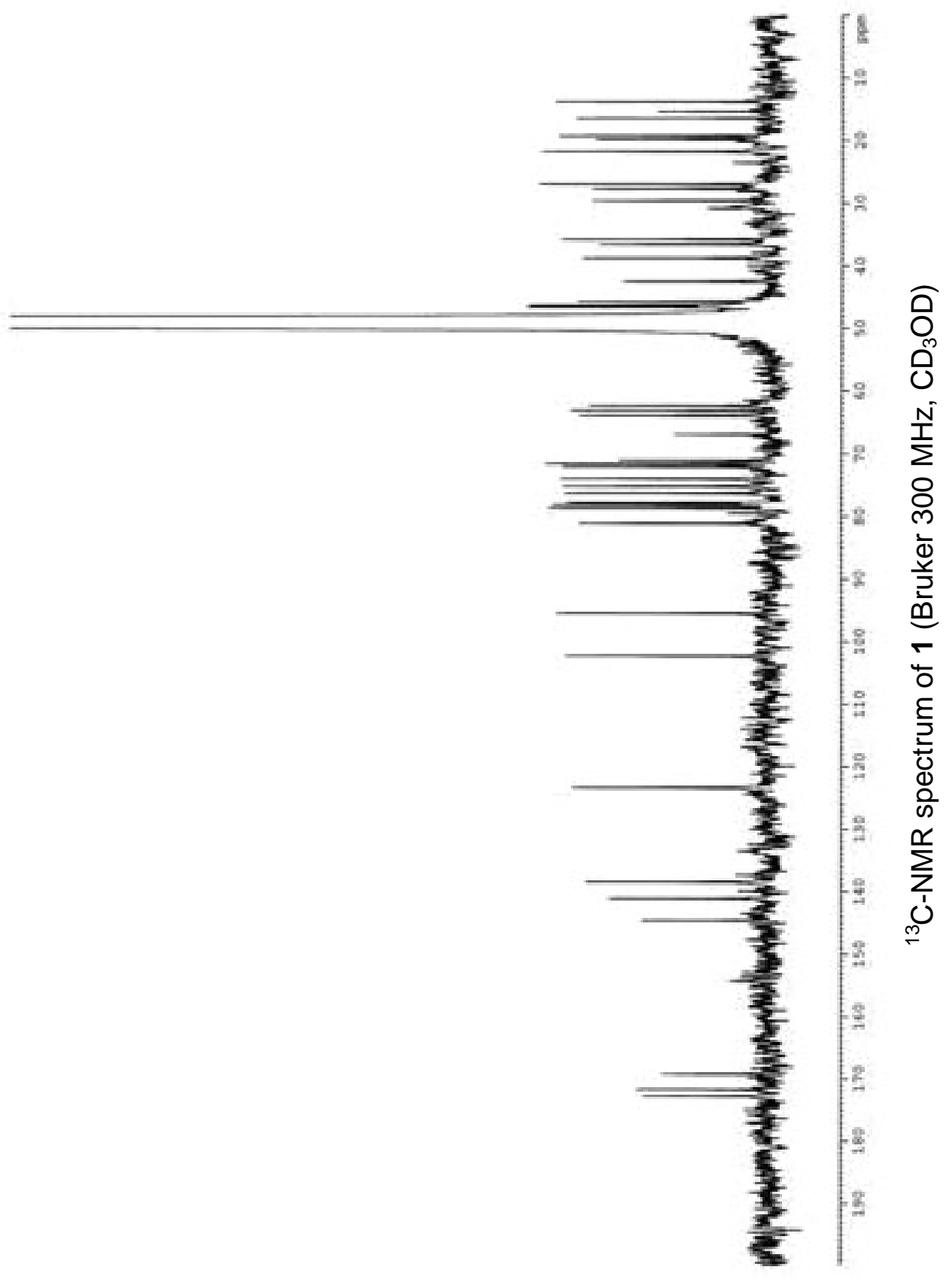




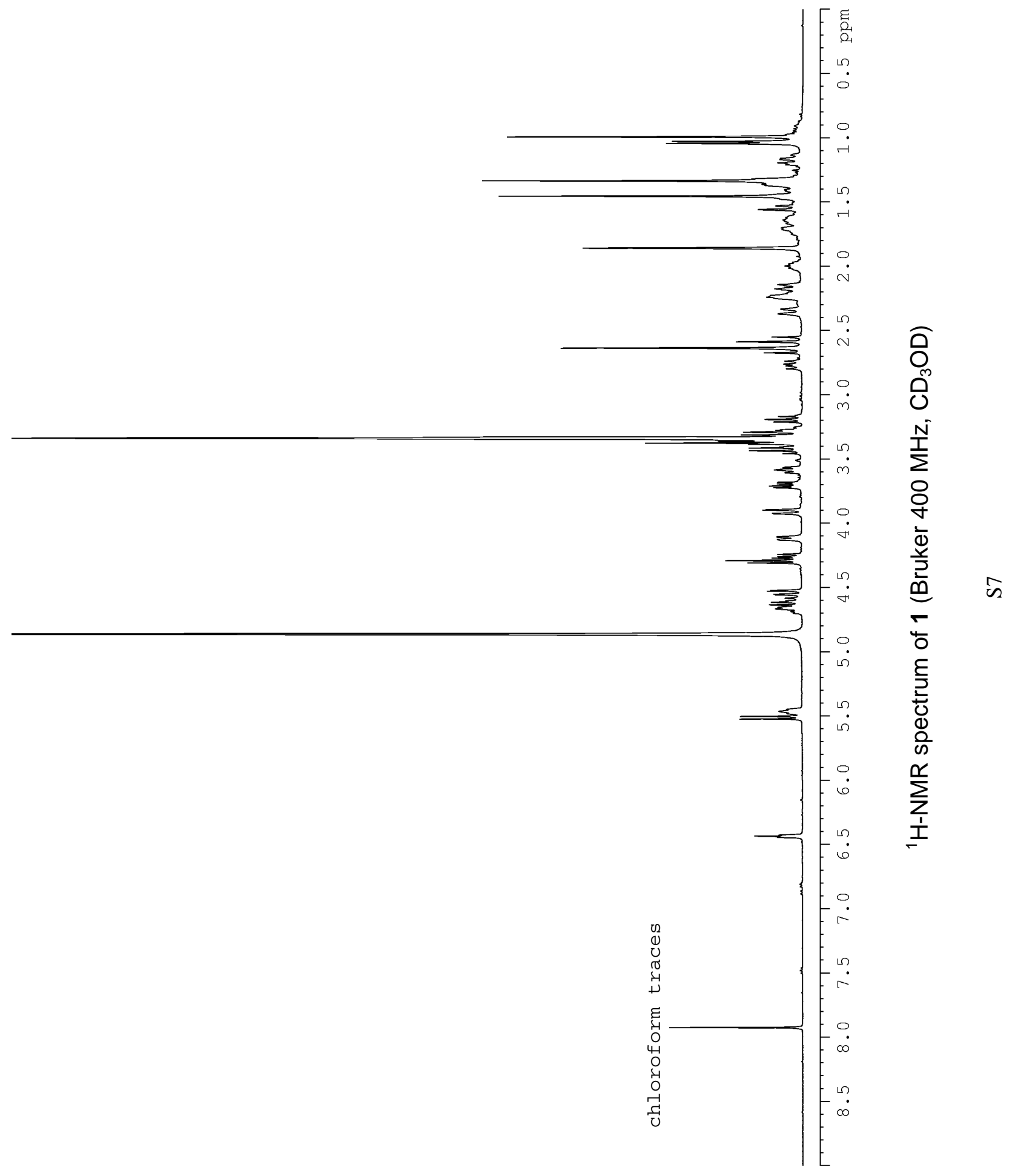




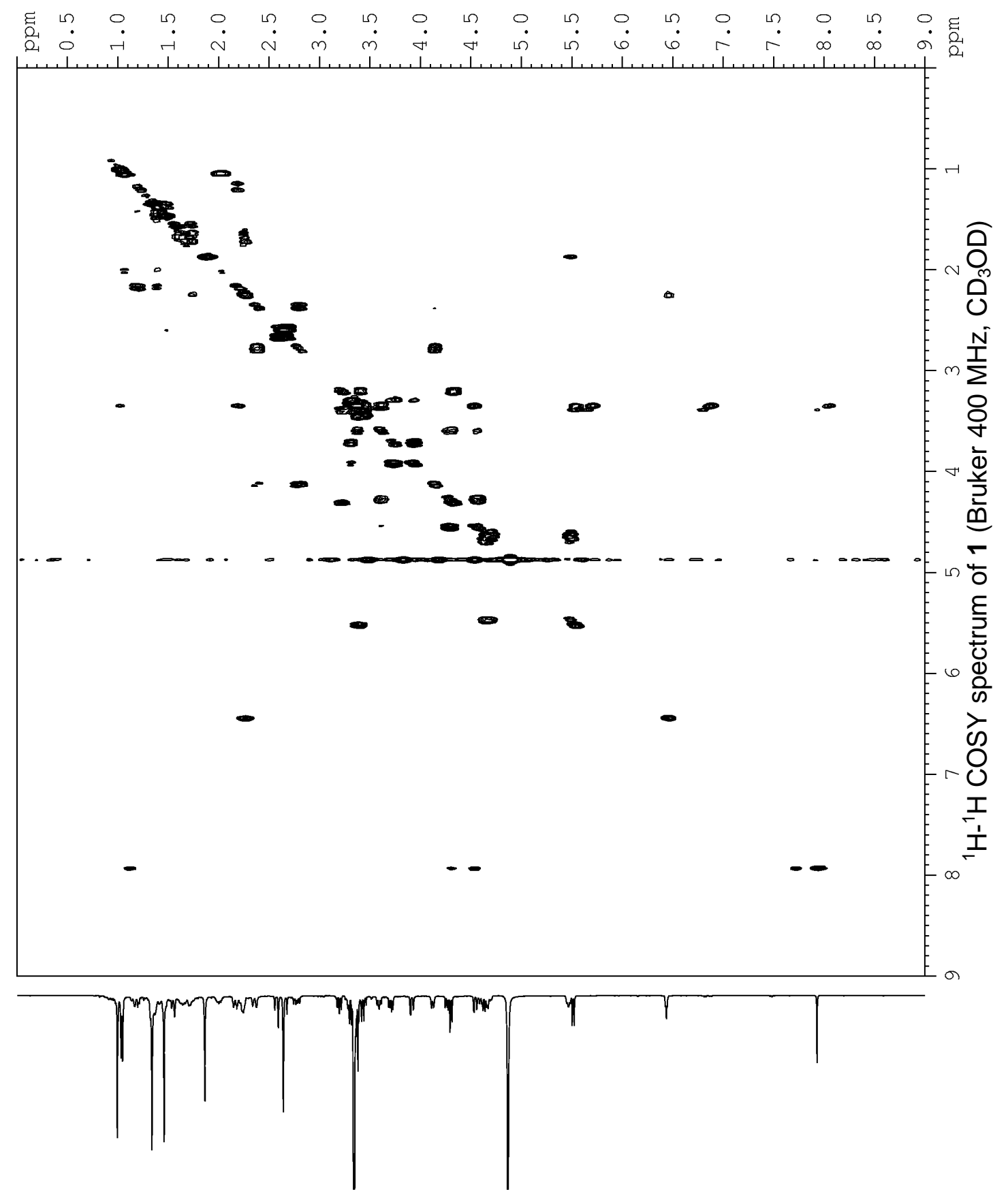




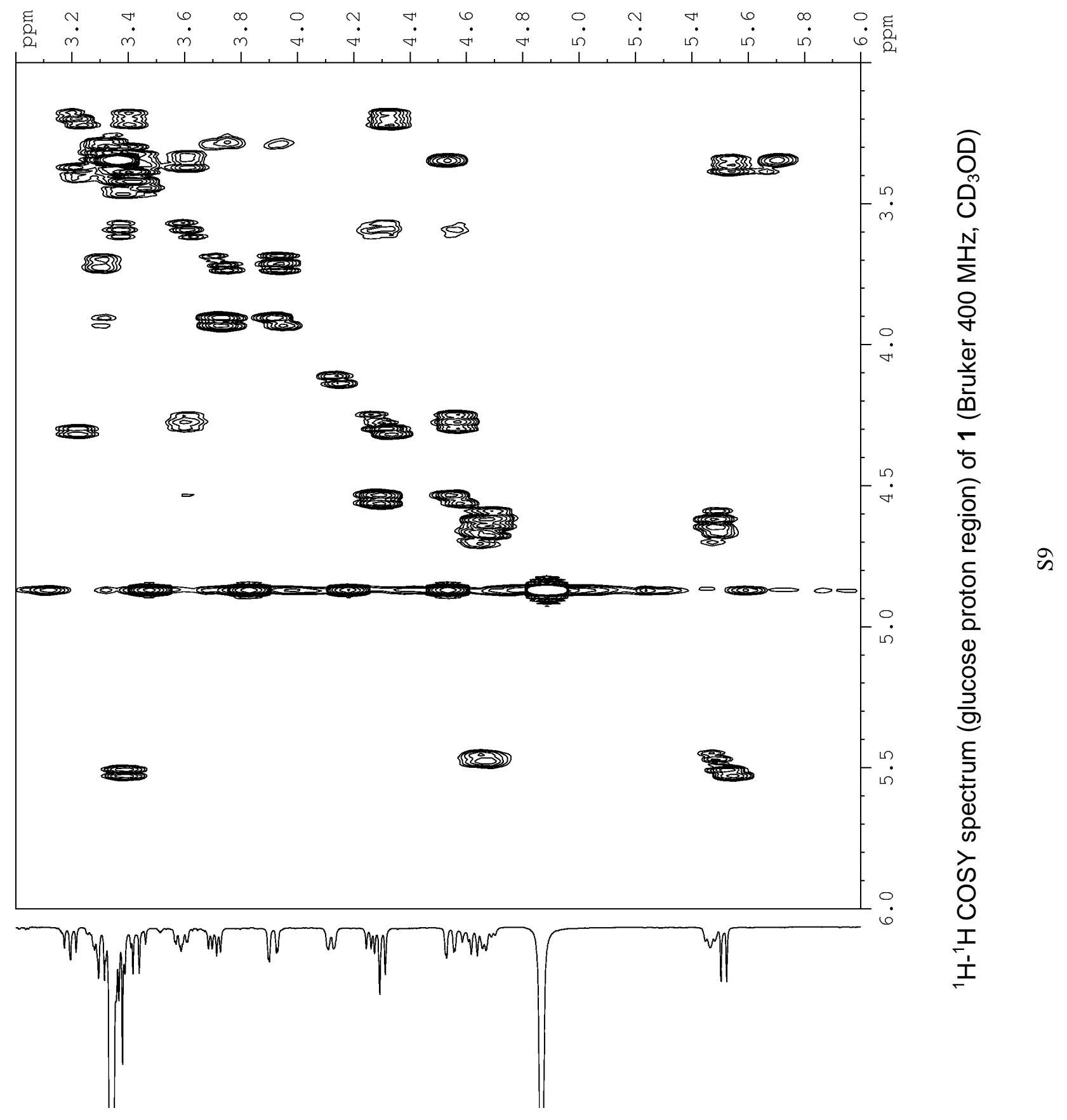




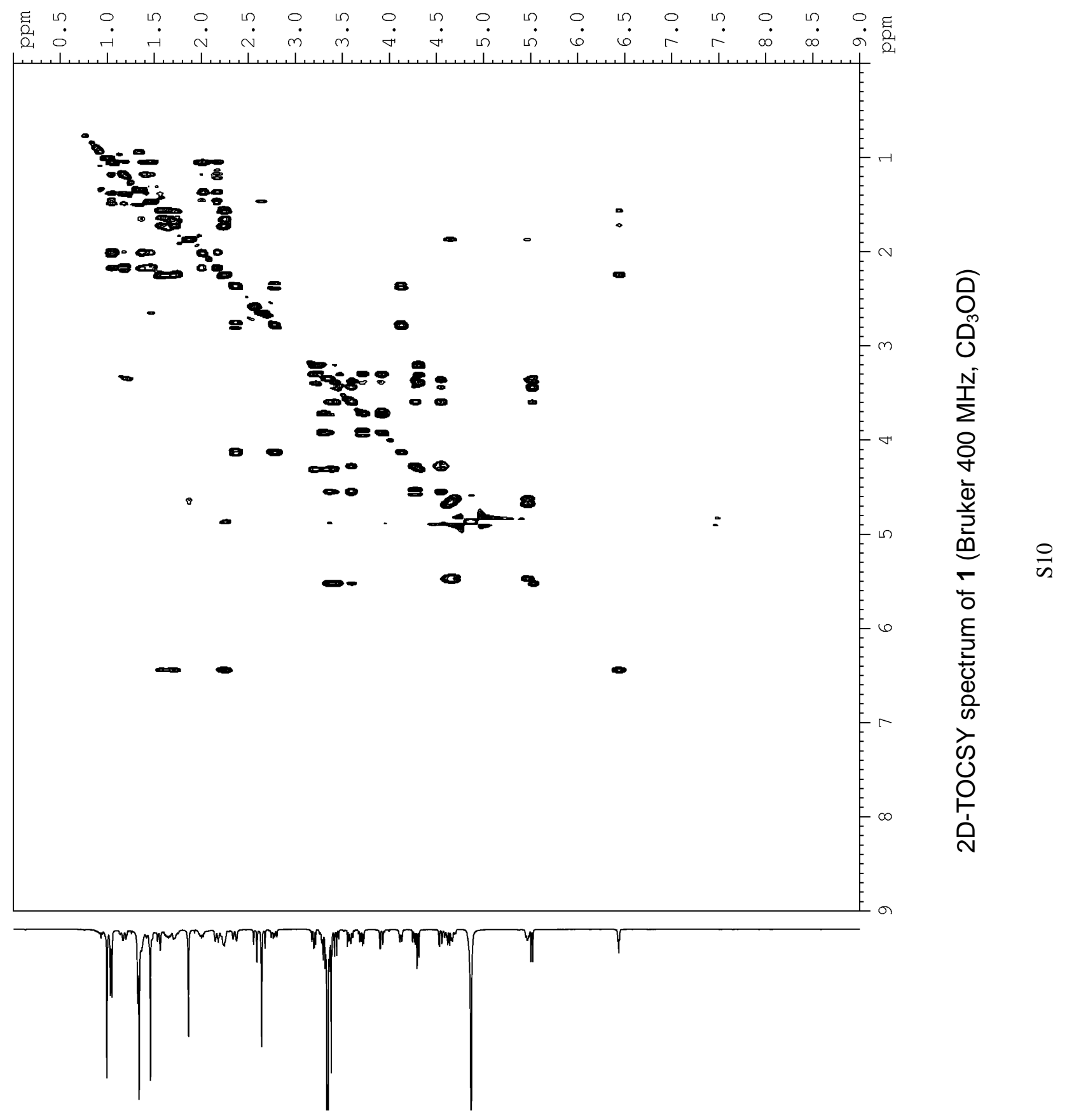




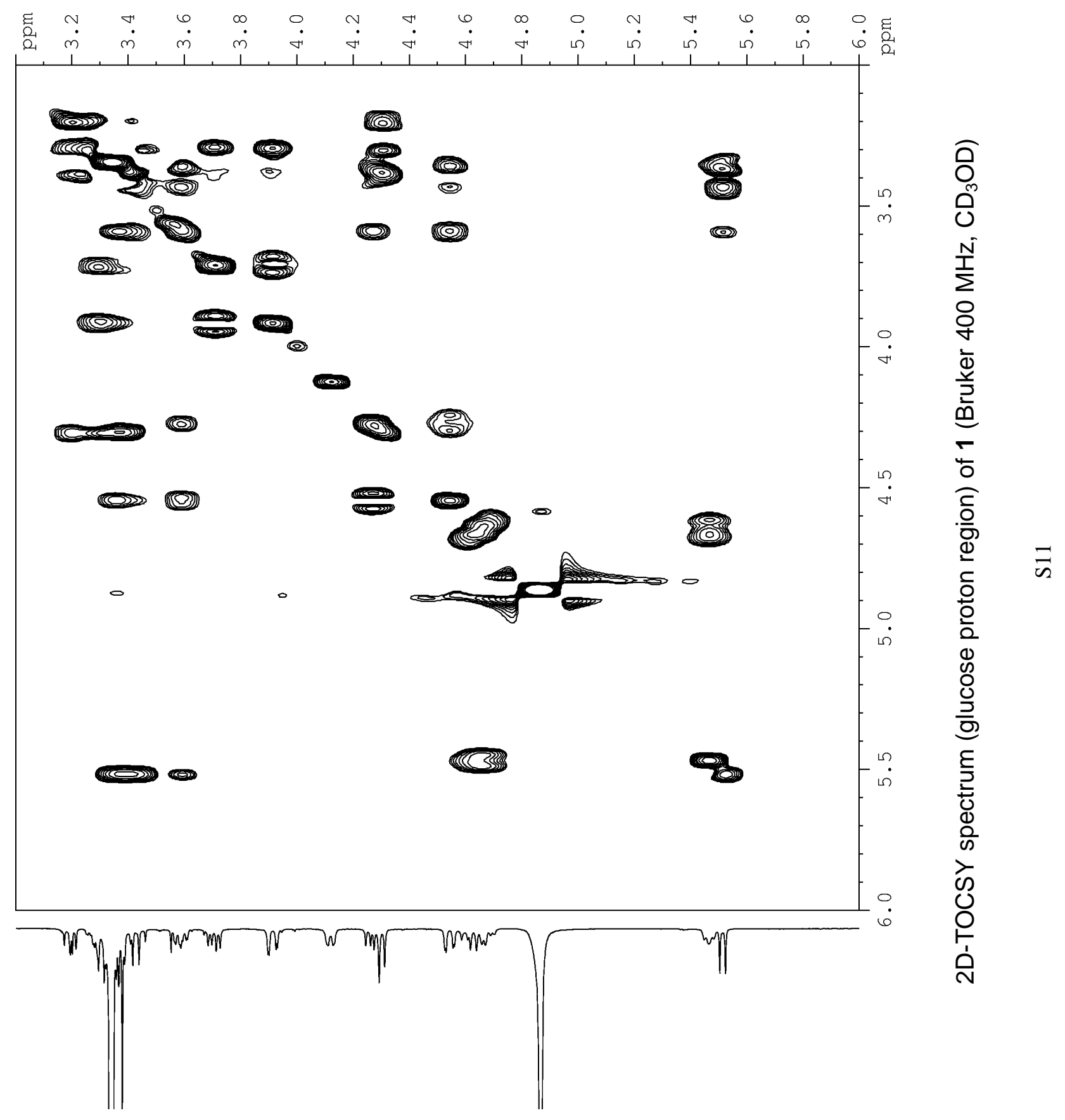




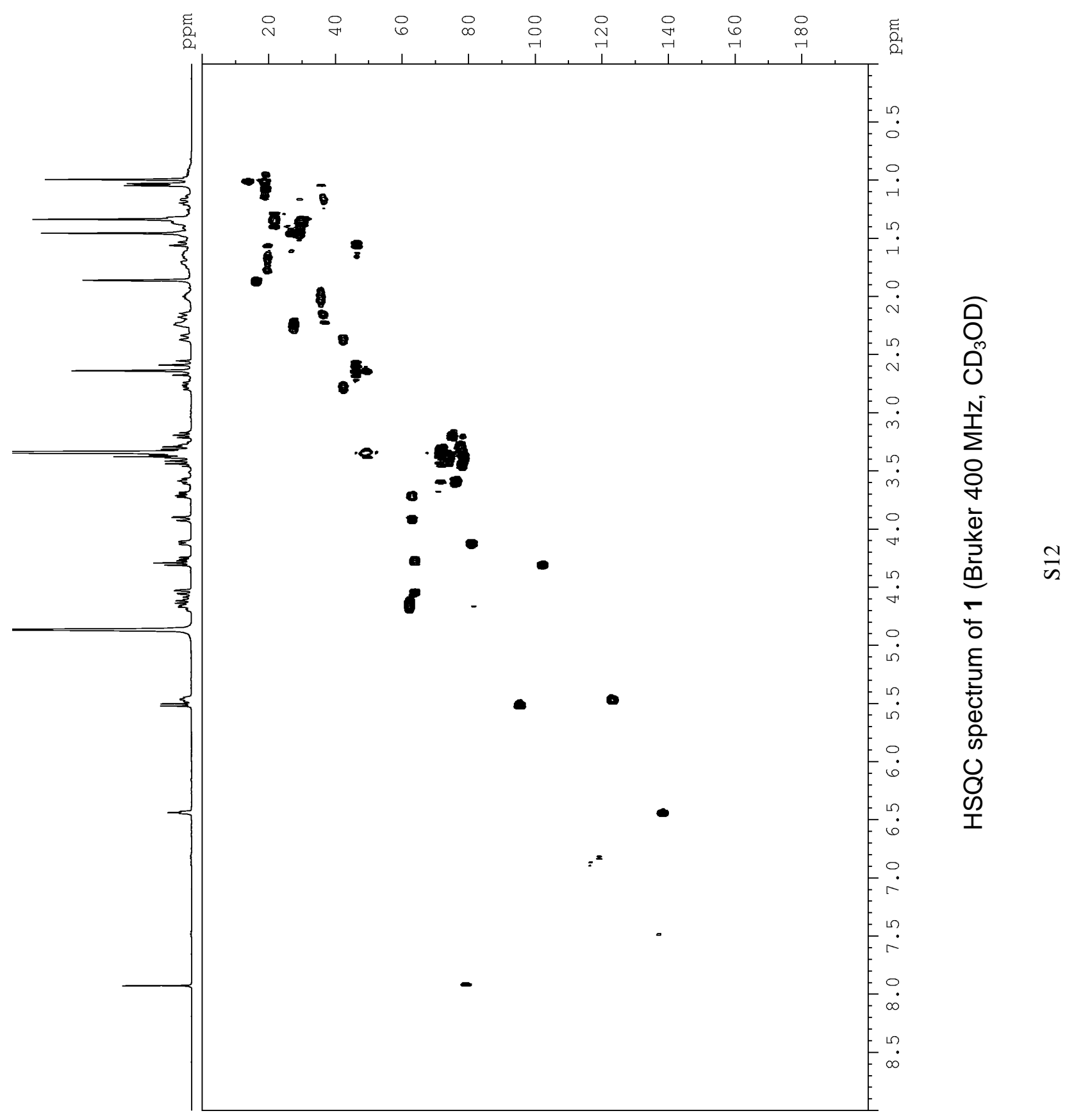




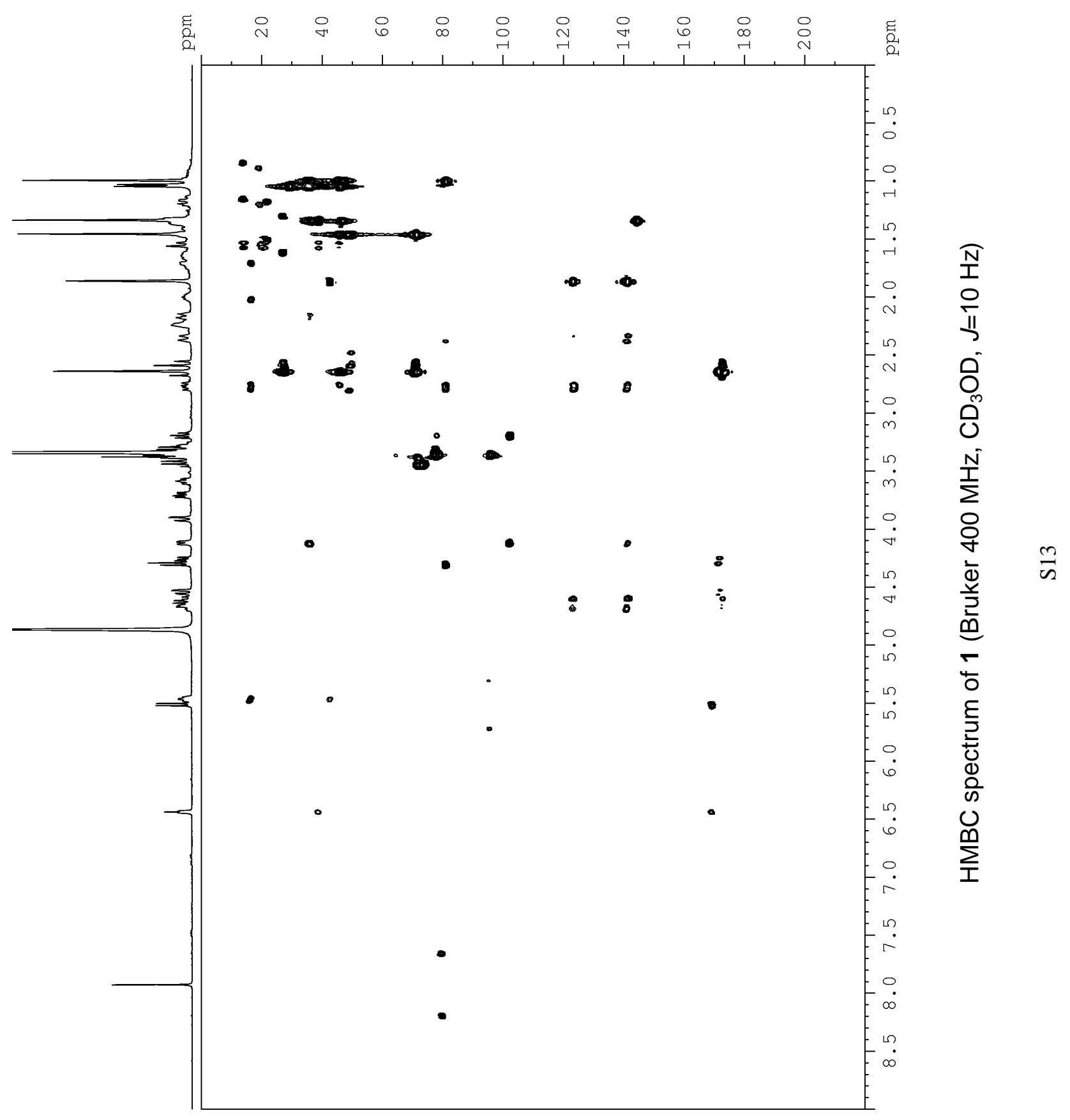




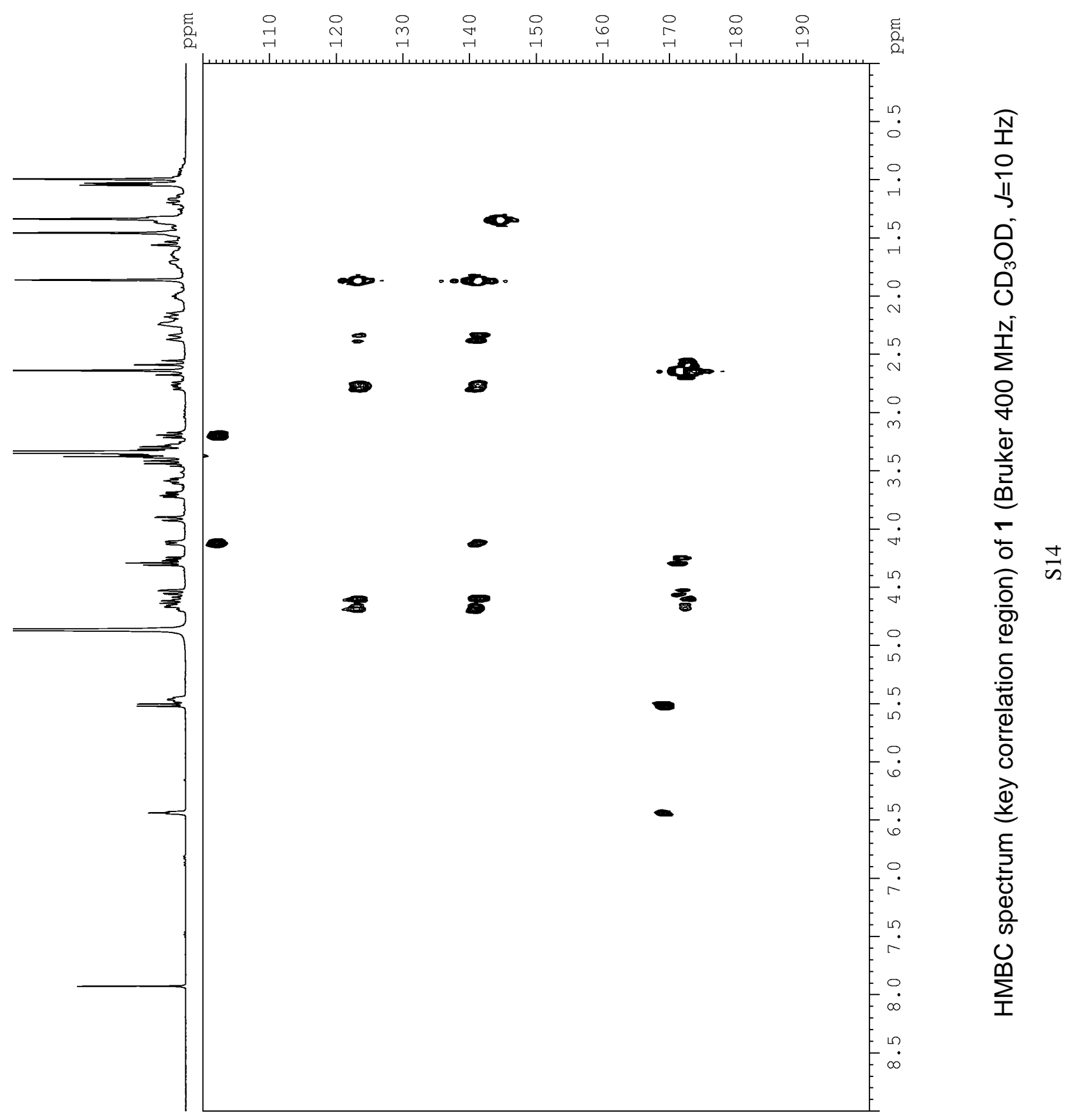




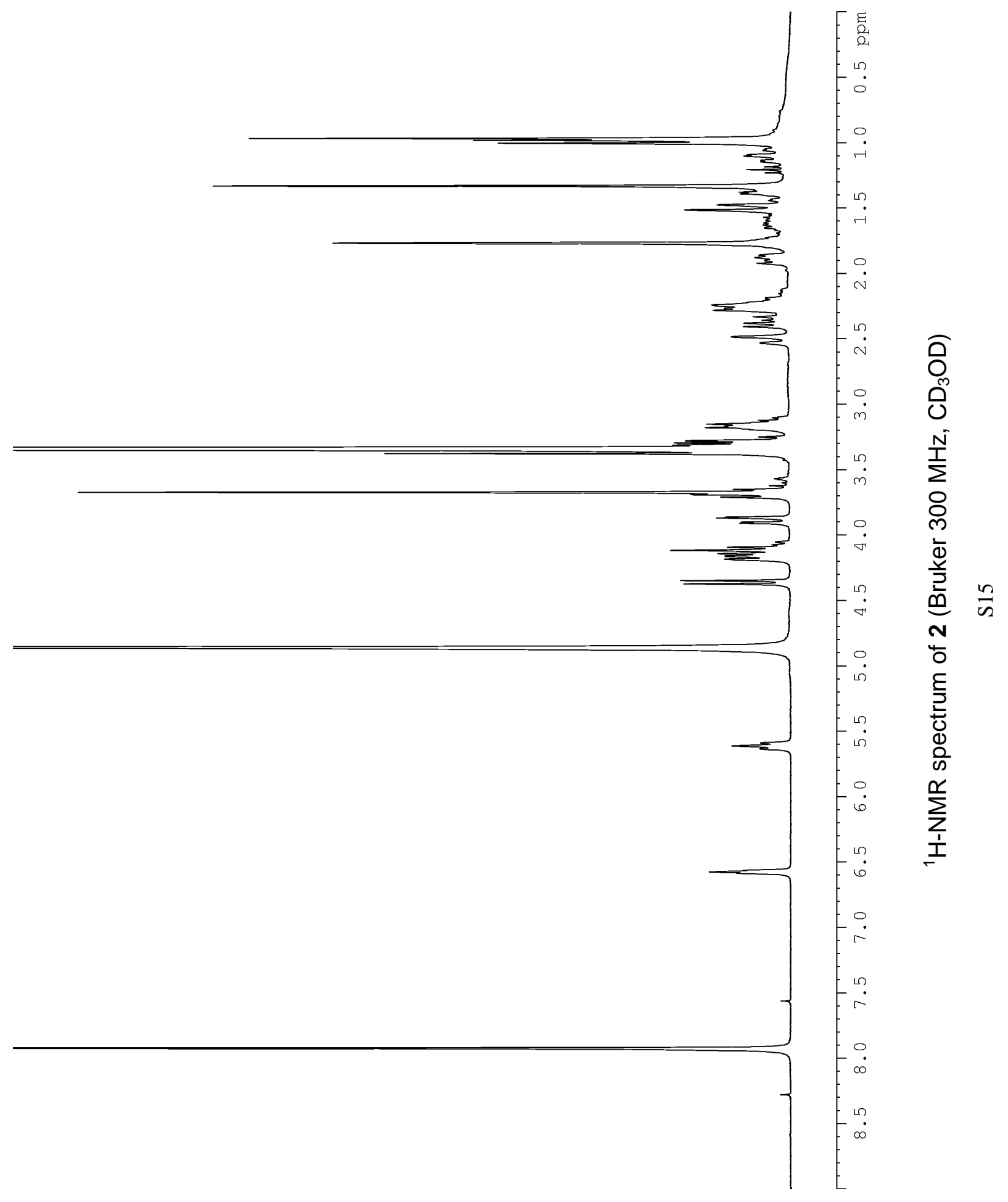




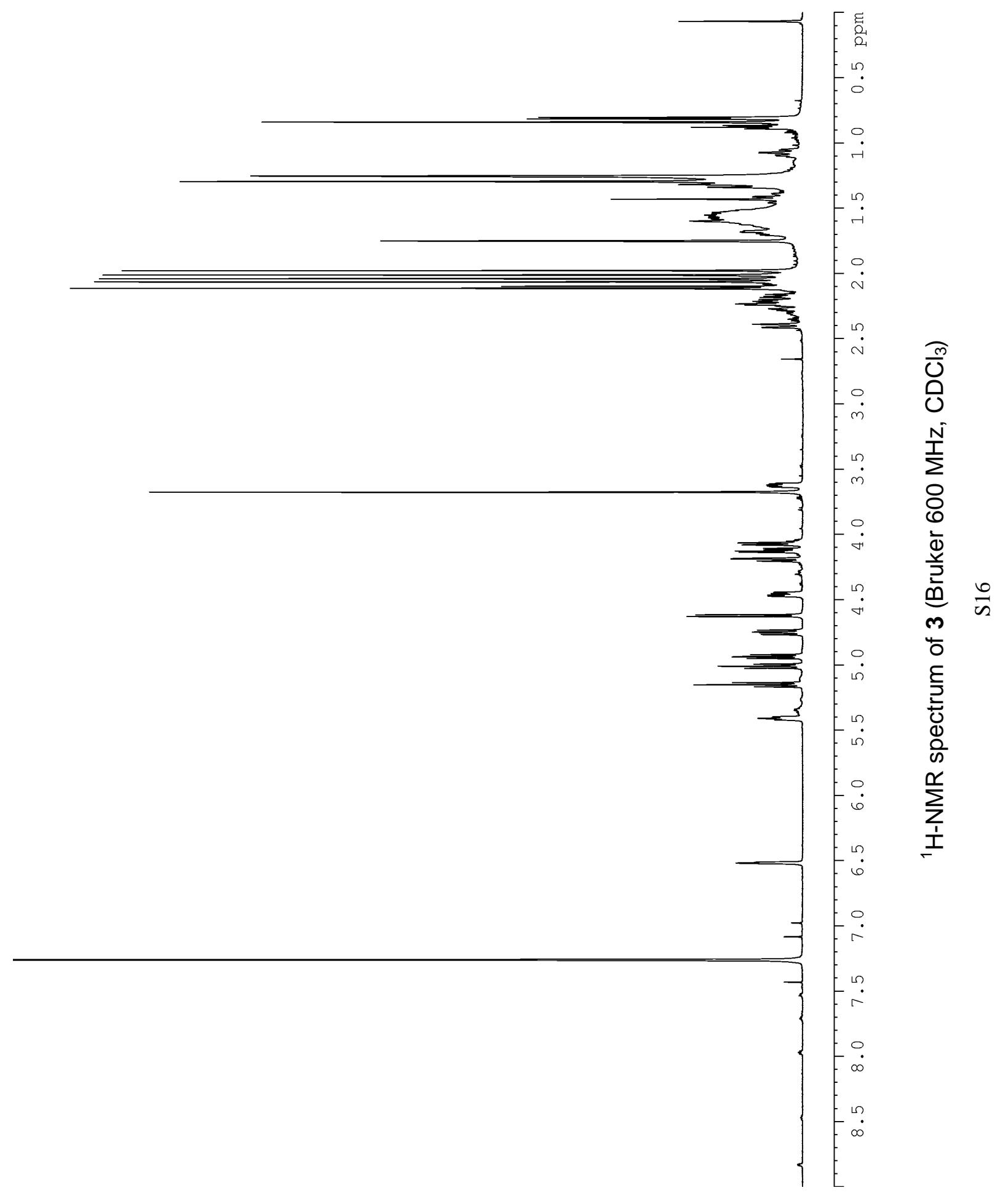




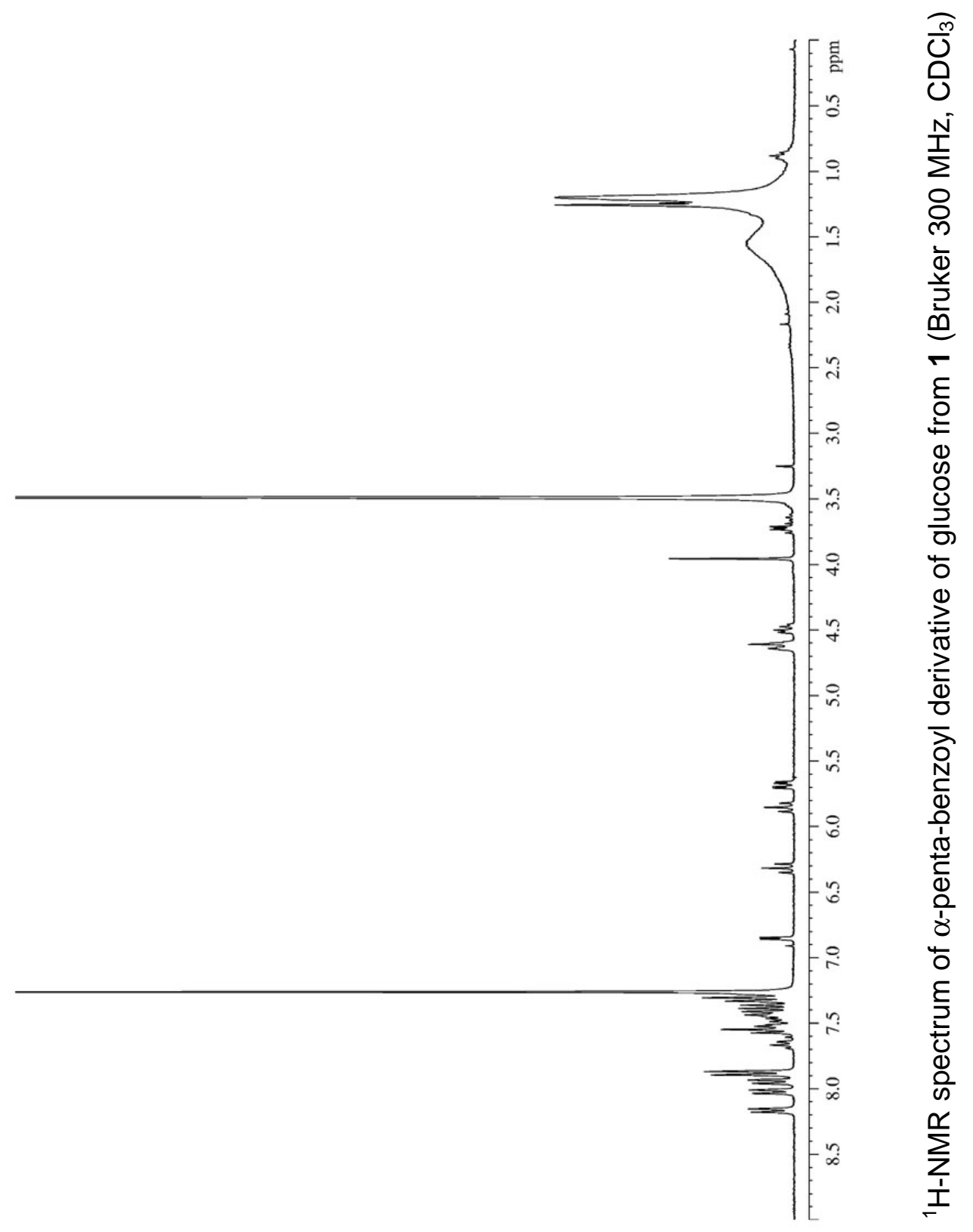




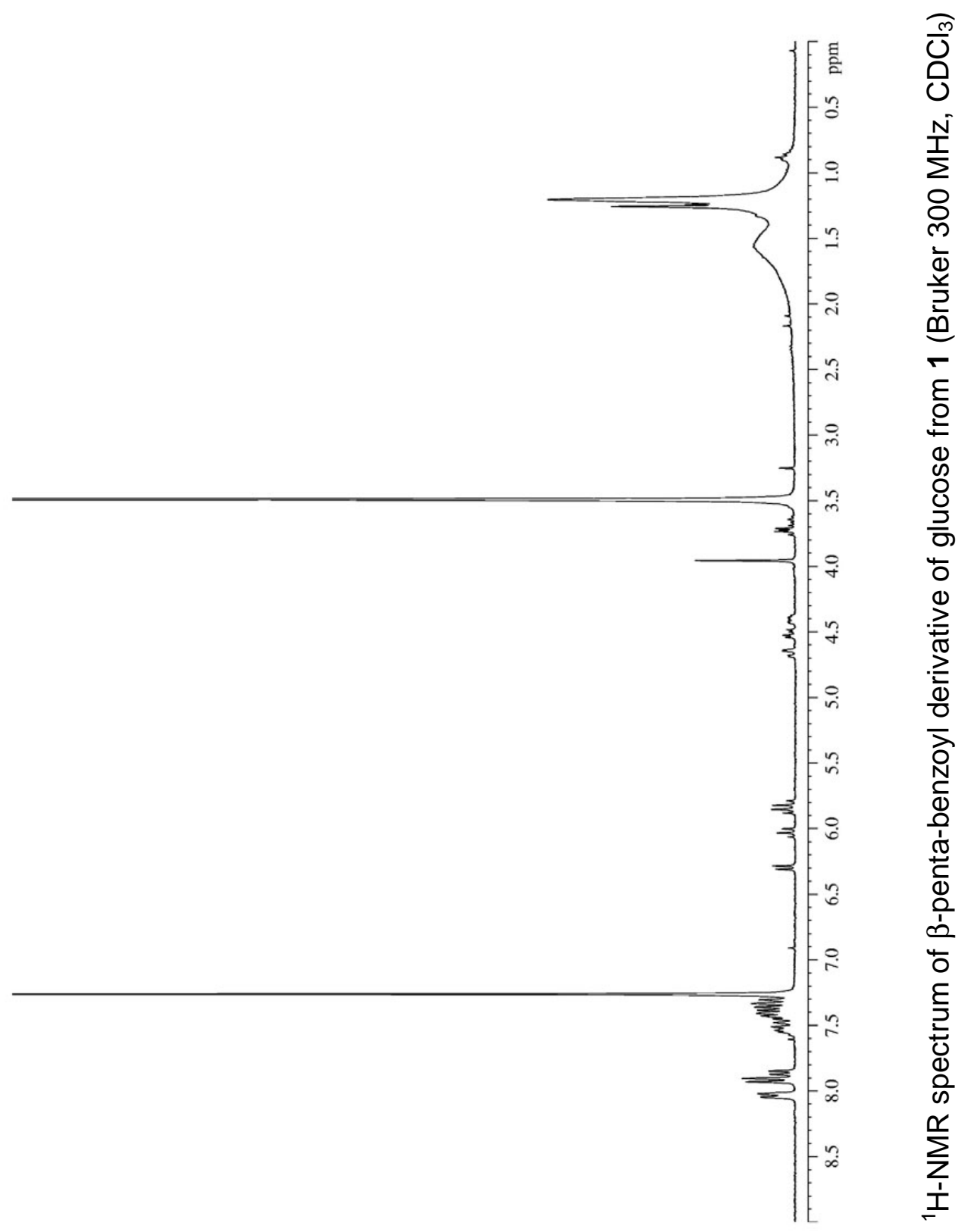




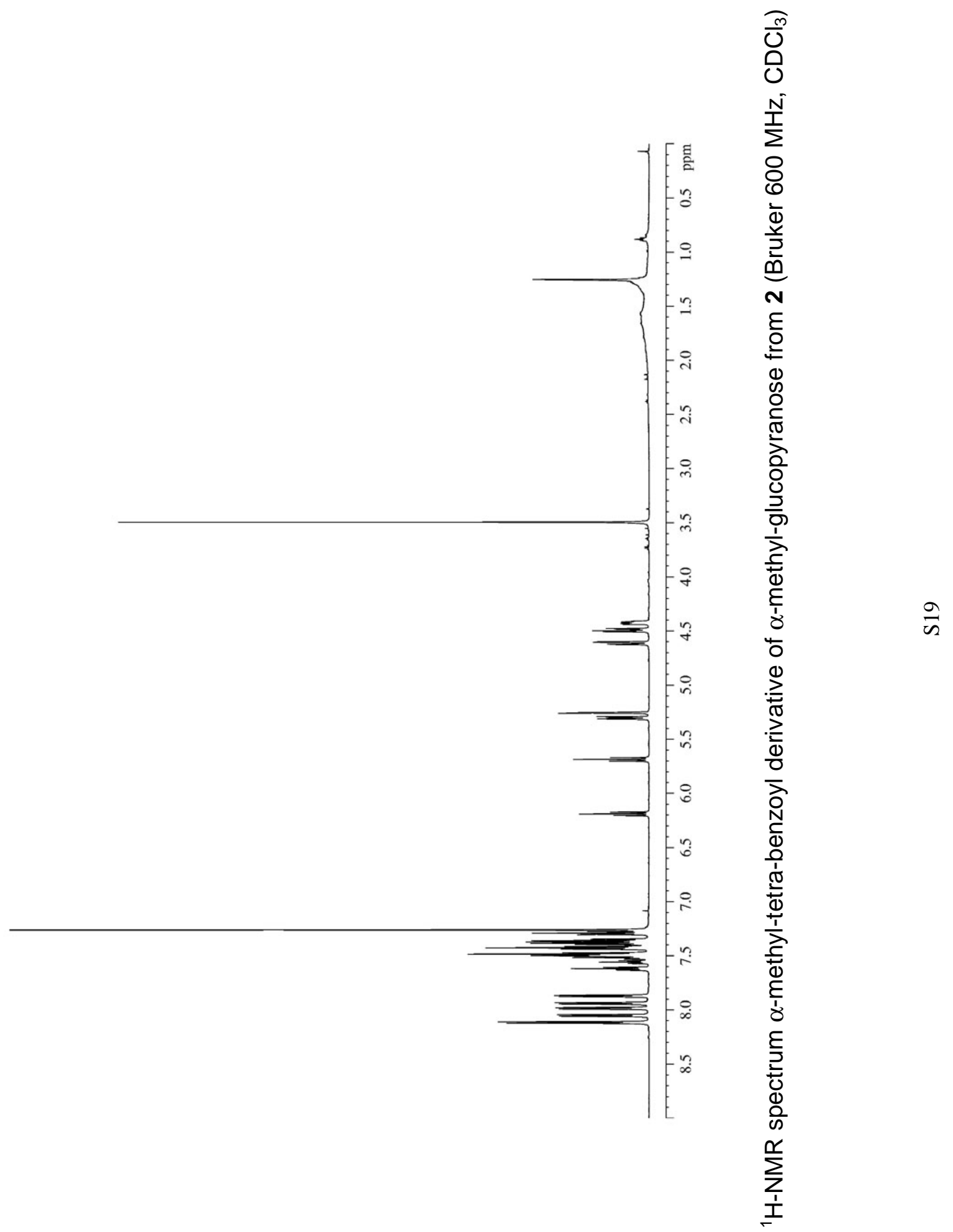




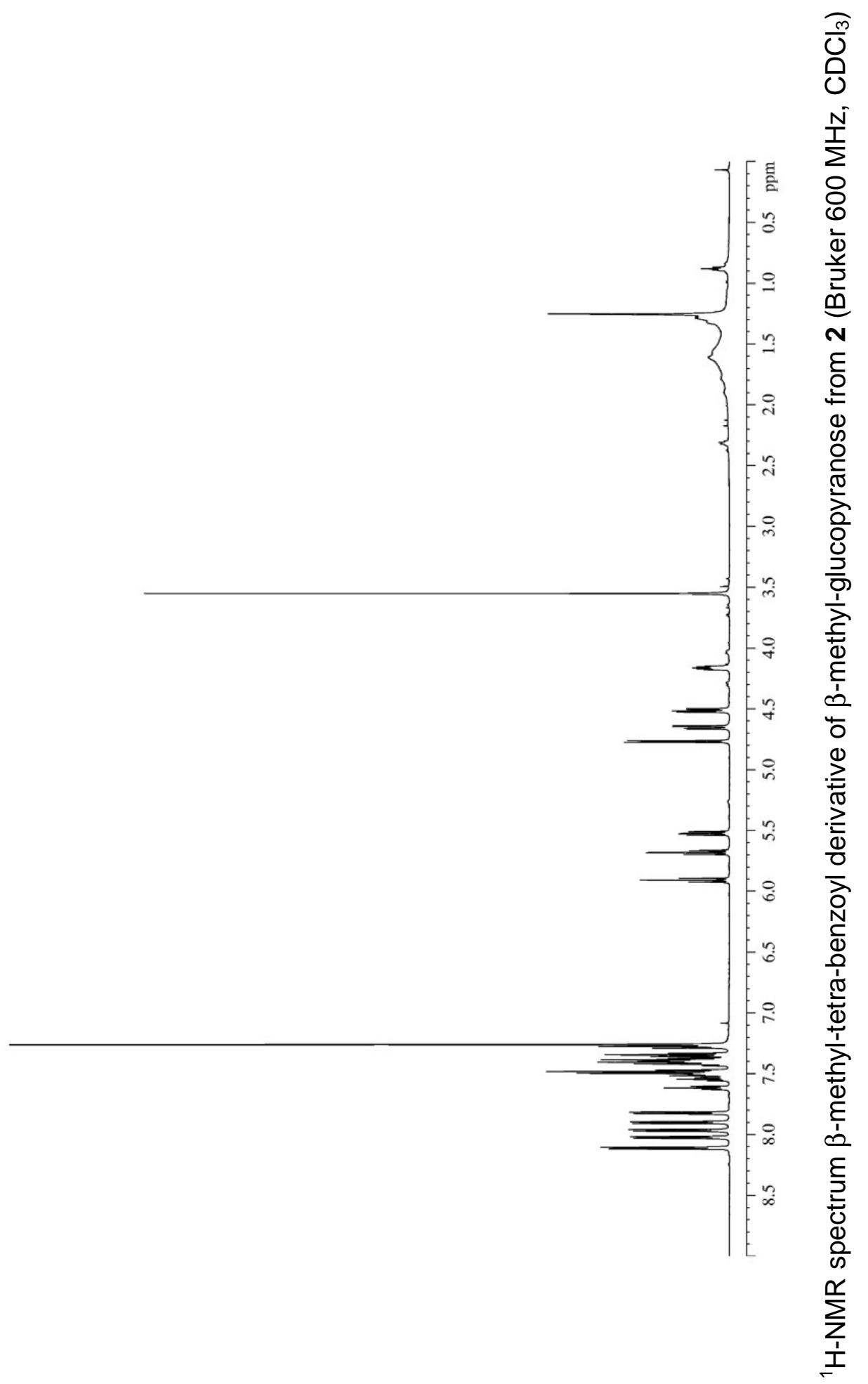



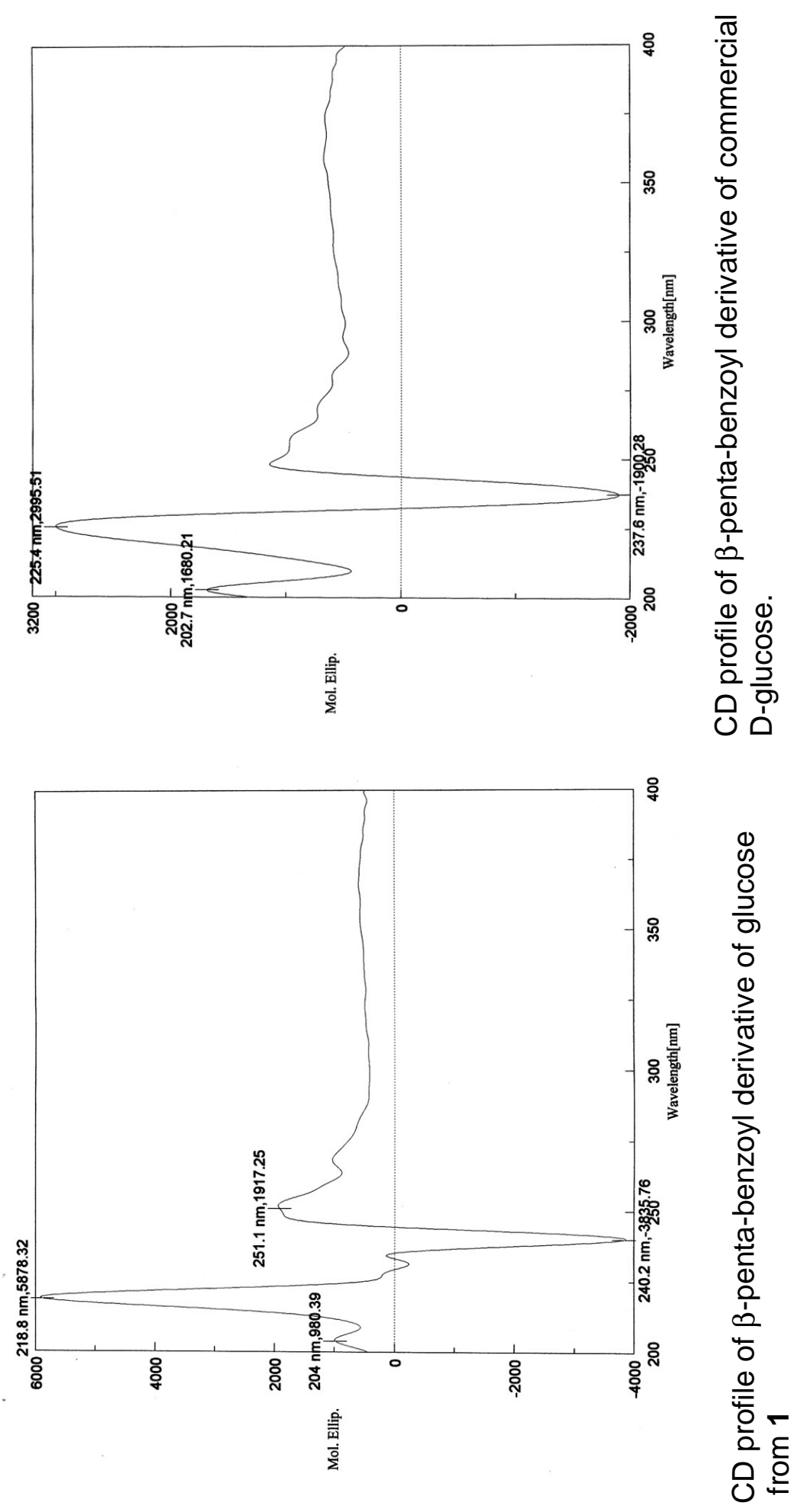

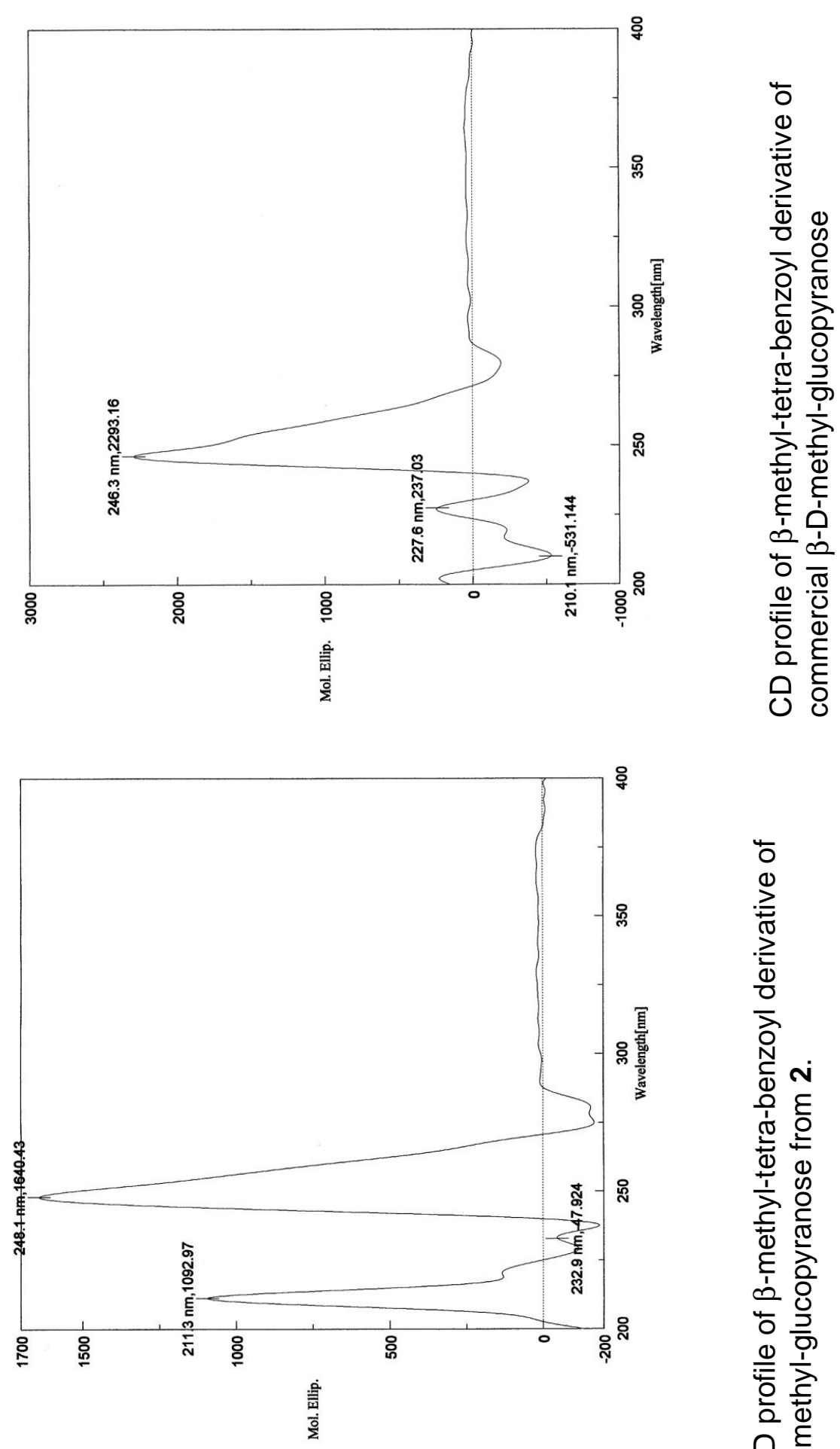

तี

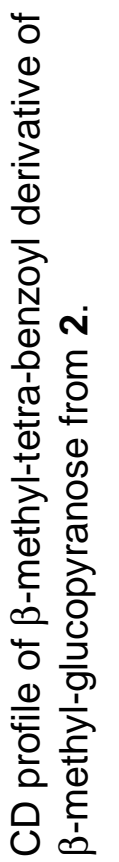

